University of Nebraska - Lincoln

DigitalCommons@University of Nebraska - Lincoln

Agronomy \& Horticulture -- Faculty Publications

Agronomy and Horticulture Department

7-2007

\title{
Influence of Planting Date and Weed Interference on Sweet Corn Growth and Development
}

Martin M. Williams II

mmwillms@uiuc.edu

John L. Lindquist

University of Nebraska-Lincoln, jlindquist1@unl.edu

Follow this and additional works at: https://digitalcommons.unl.edu/agronomyfacpub

Part of the Plant Sciences Commons

Williams II, Martin M. and Lindquist, John L., "Influence of Planting Date and Weed Interference on Sweet Corn Growth and Development" (2007). Agronomy \& Horticulture -- Faculty Publications. 381.

https://digitalcommons.unl.edu/agronomyfacpub/381

This Article is brought to you for free and open access by the Agronomy and Horticulture Department at DigitalCommons@University of Nebraska - Lincoln. It has been accepted for inclusion in Agronomy \& Horticulture -Faculty Publications by an authorized administrator of DigitalCommons@University of Nebraska - Lincoln. 


\title{
Influence of Planting Date and Weed Interference on Sweet Corn Growth and Development
}

\author{
Martin M. Williams II* and John L. Lindquist
}

\begin{abstract}
Crop planting date and canopy density influence interactions between weeds and sweet corn (Zea mays L.); however, little is known about sweet corn growth response to weed interference. Field studies were conducted in 2004 and 2005 near Urbana, IL, to quantify the influence of planting date and weed interference on growth of sweet corn height, leaf area, aboveground biomass, and phenological development. Crop growth response to weed interference (presence or absence) was determined for sweet corn planted early May (EARLY) and late June (LATE). Dominant weed species included barnyardgrass [Echinochloa crus-galli (L.) Beauv.], common lambsquarters (Chenopodium album L.), common purslane (Portulaca oleracea L.), green foxtail [Setaria viridus (L.) Beauv.], redroot pigweed (Amaranthus retroflexus $\mathbf{L}$.), and velvetleaf (Abutilon theophrasti Medicus) at densities ranging from 95 to 256 plants $\mathrm{m}^{-2}$. Weed interference reduced sweet corn's absolute height growth rate, maximum leaf area index (LAI), absolute LAI growth rate, with some of the largest effects on crop growth observed in the EARLY planting date. Silk emergence was delayed by weeds for EARLY planted sweet corn, but not LATE. Moreover, the LATE planting date resulted in 9\% taller crop plants with $36 \%$ lower maximum LAI. Relative to an EARLY planting date, lower yield losses due to weeds for LATE sweet corn correspond to greater resiliency of crop growth and silk emergence to weed interference.
\end{abstract}

$\mathrm{M}$ ANAGING WEED POPULATIONS through modification of the crop canopy has been investigated as a component of integrated weed management in dent corn (Zea mays L.) (e.g., Lindquist and Mortensen, 1998). The overall goal has been to improve the crop's ability to establish dominance over the weed, aimed specifically at preempting resources, enduring competitive stress, or avoiding stress (Jannink et al., 2000; Jordan, 1993). A number of cultural practices have been studied, including alteration in population density (Begna et al., 2001; Nurse and DiTommaso, 2005; Tharp and Kells, 2001), row spacing (Begna et al., 2001; Norsworthy and Oliveira, 2004), or corn leaf orientation (Toler et al., 1999). Moreover, identification of important canopy traits responsible for stress tolerance and weed suppression has provided the basis for directing crop breeding efforts (Jannink et al., 2000; Lemerle et al., 2006; Jordan, 1993; Tollenaar and $\mathrm{Wu}, 1999)$.

Variation in canopy properties in sweet corn is large and has practical implications for weed management.

M.M. Williams II, USDA-ARS, Invasive Weed Management Research, Univ. of Illinois, 1102 S. Goodwin Ave., Urbana, IL 61801; and J.L. Lindquist, Dep. of Agronomy and Horticulture, Univ. of Nebraska, 201 KCR, Lincoln, NE 68583. Received 4 Jan. 2007. *Corresponding author(mmwillms@uiuc.edu).

Published in Agron. J. 99:1066-1072 (2007).

Weed Management

doi:10.2134/agronj2007.0009

(C) American Society of Agronomy

677 S. Segoe Rd., Madison, WI 53711 USA
For instance, Pataky (1994) reported differences in vertical leaf area distribution among 11 hybrids, with total leaf area ranging from 2540 to $4660 \mathrm{~cm}^{2}$ per plant. Higher sweet corn maximal leaf area index (LAI) from anthesis to harvest conferred greater suppression of wild proso millet (Panicum miliaceum L.), and LAI at the 120 - to $150-\mathrm{cm}$ height was negatively correlated to weed growth and fecundity (Williams et al., 2007). With a crop population density of 56800 plants ha ${ }^{-1}$, effect of sweet corn hybrid was more important than crop row spacing (51 vs. $76 \mathrm{~cm}$ ) for intercepting light and influencing growth of wild proso millet and green foxtail (Bisikwa, 2001).

Planting date has a significant effect on crop-weed interactions. Velvetleaf fecundity was reduced by delayed dent corn planting dates (Nurse and DiTommaso, 2005). Delayed planting reduced yield losses due to weeds in soybean [Glycine max (L.) Merr.] (Buhler and Gunsolus, 1996) and dent corn (Gower et al., 2002), explained largely by an increase in weed seedling mortality with delayed planting date. Delayed dent corn planting had lower weed densities in 1 of $2 \mathrm{yr}$, and efficacy of rotary hoeing increased with delayed planting (Mulder and Doll, 1994). Critical period of weed control (CPWC), the phase of the crop growth cycle when weed interference results in unacceptable yield loss, began 500 growing degree days (GDD) earlier in sweet corn planted the first week of May relative to a mid-June planting in Illinois, despite comparable weed species composition and density (Williams, 2006). Factors other than weed density account for differences observed in CPWC, and may include crop growth response to planting date.

The amount of time required to reach sweet corn maturity is influenced by planting date (Kwabiah, 2004), primarily due to variation in temperature environment during growth. However, the extent to which planting date influences sweet corn growth and canopy development is poorly understood. Crop modeling has been used to determine optimal planting dates for dent corn (Anapalli et al., 2005). Nielsen et al. (2002) reported thermal time of silk emergence and grain-fill period decreased as planting was delayed from early May to mid-June. In temperate climates, full-season dent corn hybrids can be exposed to potentially lethal cold temperatures before grain maturation when planting is delayed. Sweet corn hybrids often mature earlier than dent corn in North America and are sown over a range of planting dates to extend availability for fresh market

Abbreviations: BIO, biomass per unit area; CPWC, critical period of weed control; EARLY, early May planting date; GDD, growing degree days; HT, canopy height; LAI, leaf area index; LATE, late June planting date; SSC, soluble solids concentration. 
and processing, spanning 3 mo in the north-central USA (Tracy, 2001). Response of sweet corn to weeds is likely to vary with planting date since the effects of weeds tends to be linked with the growth and competitiveness of the crop. While canopy development has been described among some processing hybrids (Williams et al., 2006), there appear to be no reports on the influence of planting date on sweet corn growth and development. Therefore, the objective of this research was to quantify the influence of planting date and weed interference on growth of sweet corn height, leaf area, aboveground biomass, and phenological development.

\section{MATERIALS AND METHODS Site Description}

Field experiments were conducted in 2004 and 2005 at the University of Illinois, Cruse Tract Vegetable Research Farm near Urbana $\left(40^{\circ} 4^{\prime} \mathrm{N}, 88^{\circ} 12^{\prime} \mathrm{W}\right)$. The soil was a Flanagan silt loam (fine, smectitic, mesic Aquic Argiudolls) averaging $3.6 \mathrm{~g} \mathrm{~kg}^{-1}$ organic matter and $\mathrm{pH}$ of 6.4 . Experiments were located in different fields in each year. Previous crops were alfalfa (Medicago sativa L.) and soybean for the 2004 and 2005 experiments, respectively. Fields received a broadcast application of granular fertilizer including $129 \mathrm{~kg} \mathrm{~N} \mathrm{ha}^{-1}, 113 \mathrm{~kg} \mathrm{P} \mathrm{ha}^{-1}$, and $135 \mathrm{~kg} \mathrm{~K} \mathrm{ha}^{-1}$ on 23 Mar. 2004 and 16 Mar. 2005.

\section{Experimental Approach}

The experiment followed a split-plot design with four replications. The main plot factor was planting date, which consisted of seeding sweet corn in the first week of May, hereafter referred to as EARLY, and the third week of June, hereafter referred to as LATE. The experimental area was chisel plowed in the fall or spring, followed by one pass each of a disk harrow and a field cultivator before planting. Glufosinate-tolerant sweet corn (cv. GH0937, a mid-season sugary1 endosperm mutant) was planted in $0.76-\mathrm{m}$ rows at 70423 seeds ha ${ }^{-1}$ on 6 May (EARLY) and 21 June (LATE) in 2004 and 2 May (EARLY) and 20 June (LATE) in 2005.

Subplot treatments consisted of presence (weedy) or absence (weed-free) of weed interference, such that weed presence was a random effect over time. Subplots measured $12.2 \mathrm{~m}$ in length by 4 rows wide $(3.0 \mathrm{~m})$. A preemergence application of $1.78 \mathrm{~kg}$ a.i. ha ${ }^{-1} S$-metolachlor (2-chloro- $N$-(2-ethyl-6methylphenyl)- $N$-(2-methoxy-1-methylethyl)acetamide) and $2.2 \mathrm{~kg}$ a.i. ha ${ }^{-1}$ atrazine (6-chloro- $N$-ethyl- $N^{\prime}$-(1-methylethyl)1,3,5-triazine-2,4-diamine) was applied to weed-free plots the day of crop planting, and all subsequent emerging weeds were removed by hoe or hand.

The experimental site was irrigated four times in 2005 (7 June, 21 June, 29 June, and 9 August). Each irrigation event totaled $2.5 \mathrm{~cm}$ of water to offset abnormally low rainfall. Permethrin (3-phenoxybenzyl(1RS)-cis,trans-3-(2,2-dichlorovinyl)-2,2-dimethylcyclopropanecarboxylate) was applied in both years at $168 \mathrm{~g}$ a.i. ha $^{-1}$ to control western corn rootworm (Diabrotica virgifera virgifera LeConte) beetles as needed.

\section{Data Collection}

Based on growth stage in the weed-free treatment, sweet corn growth was determined in weed-free and weedy subplots at V2, V4, V6, V8, R1 (silk emergence), and R3 (harvest) (Ritchie et al., 2003). Three consecutive corn plants per plot were cut at the soil surface in rows 1 and 4 through the V6 sampling time, then rows 2 and 3 for later sampling times. Crop growth stage and plant height from the plant base to apex were recorded for 10 consecutive plants. Leaves were separated from stems by cutting the lamina at the ligule, while newly emerged leaves were separated at the uppermost visible collar. Leaf area was determined using an area meter (LI-3100C Area Meter, LI-COR, Lincoln, NE) and plant biomass was ovendried at $65^{\circ} \mathrm{C}$ for 4 to $6 \mathrm{~d}$.

Within 18 to $21 \mathrm{~d}$ after anthesis, marketable ears, including silks and husks, exceeded $4.4 \mathrm{~cm}$ in diameter. Harvest dates were 2 August (EARLY) and 11 September (LATE) in 2004 and 27 July (EARLY) and 30 August (LATE) in 2005. Five marketable ears from each weedy and weed-free plot were randomly selected, sealed in plastic bags, and placed on ice. Within $6 \mathrm{~h}$, ears were analyzed for kernel moisture and soluble solids concentration (SSC), indicators of relative maturity (Hale et al., 2005; Ritchie et al., 2003). Kernels were removed from the cob with an electric knife in 2004 and a power corn cutter (Power Corn Cutter, A\&K Development Co., Eugene, OR) in 2005. Percent kernel moisture was determined gravimetrically using a $20-\mathrm{g}$ sample of fresh kernels. Another $20-\mathrm{g}$ sample was ground with a mortar and pestle and then gently squeezed through $0.5-\mathrm{mm}$ nylon mesh. A digital refractometer (AR200 Digital Refractometer, Leica Microsystems, Educational and Analytical Division, Buffalo, NY) was used to determine SSC of the extract.

Thermal time accumulated from sweet corn emergence was used as the reference point for growth and development measurements. Thermal time was measured in GDD calculated using minimum and maximum air temperatures obtained from a nearby weather station (Illinois State Water Survey, 2005). A base temperature of $10^{\circ} \mathrm{C}$ was used as the minimum temperature for corn growth, and $30^{\circ} \mathrm{C}$ was used as the air temperature associated with maximum growth rate.

\section{Statistical Analyses}

Sweet corn growth in canopy height (HT), leaf area index (LAI), and biomass per unit area (BIO) as a function of thermal time were determined for each subplot. The LAI and biomass were determined from leaf area and biomass of harvested plants and total stand density within the subplot. To quantify growth over time as influenced by planting date and weed interference, data were regressed on GDD accumulated from emergence using the Richards function (Hunt, 1982):

$$
Y=\frac{Y_{\max }}{[1+\exp (a-b \mathrm{GDD})]^{1 / c}}
$$

where $Y_{\max }$ represents maximum $\mathrm{HT}$, LAI, or $\mathrm{BIO}$, and $a, b$, and $c$ are shape coefficients. The combination $b /(c+1)$ represents a weighted mean relative growth rate and $Y_{\max }$ $b /[2(c+2)]$ is a weighted mean absolute growth rate over the entire growth period (Hunt, 1982). If $c=1$, the ratio $a / b$ defines the thermal time from emergence when the maximum absolute growth rate occurs (i.e., the inflection point). Some caution is needed when interpreting this ratio because its value also is highly correlated with $Y_{\max }$ (i.e., taller plants will reach $a / b$ later). In fitting Eq. [1] to LAI over thermal time, only LAI from emergence to the R1 growth stage (before 700 GDD) were included in the analysis.

To evaluate the effects of planting date and weed interference on height, LAI, and biomass growth, Eq. [1] was fitted to these data for each subplot using PROC NLIN (SAS Institute, 1990). If the estimate of $c$ did not vary from 1.0, its value was set to a constant 1.0 in all subsequent analyses, in which case Eq. [1] reduces to a logistic function. Parameter estimates obtained for each subplot were then subjected to ANOVA to determine treatment effects. ANOVA was con- 
Table 1. Monthly rainfall and irrigation amounts and minimum, maximum, and mean average daily temperatures for the months of May, June, July, and August in 2004 and 2005 in Urbana, IL. Departure from 30-yr average precipitation and mean air temperature for these months are included for reference.

\begin{tabular}{|c|c|c|c|c|c|c|c|}
\hline \multirow[b]{2}{*}{ Month } & \multicolumn{2}{|c|}{ Water supply } & \multicolumn{3}{|c|}{ Air temp. } & \multicolumn{2}{|c|}{ Departure avg. } \\
\hline & Rainfall & Irrigation & Min. & Max. & Mean & Rainfall & Temp. \\
\hline & \multicolumn{2}{|c|}{$-\mathbf{m m} \longrightarrow$} & \multicolumn{3}{|c|}{2} & \multirow[t]{2}{*}{$\mathbf{m m}$} & \multirow[t]{2}{*}{${ }^{\circ} \mathbf{C}$} \\
\hline & & & & & & & \\
\hline May & 116 & $\mathbf{0}$ & 13.0 & 24.4 & 18.7 & -6 & +1.7 \\
\hline June & 96 & 0 & 15.2 & 26.6 & 20.9 & -11 & -1.2 \\
\hline July & 146 & 0 & 17.4 & 27.7 & 22.6 & +27 & -1.4 \\
\hline Aug & 91 & 0 & 14.3 & 25.9 & 20.1 & -20 & -2.7 \\
\hline \multicolumn{8}{|c|}{2005} \\
\hline May & 25 & $\mathbf{0}$ & 9.1 & 23.5 & 16.3 & -97 & -0.7 \\
\hline June & 61 & 194 & 17.6 & 30.1 & 23.9 & -45 & $+\mathbf{1 . 8}$ \\
\hline July & 109 & o & 18.6 & 30.3 & 24.5 & -9 & +0.6 \\
\hline Aug & 57 & 65 & 18.7 & 29.9 & 24.3 & -55 & +1.6 \\
\hline
\end{tabular}

ducted using the PROC MIXED procedure (Littell et al., 1996) to compute least squares means, standard errors, and treatment differences at the $\alpha=0.05$ level. Since planting date $\times$ weed interference interaction effects were typically significant, Eq. [1] was again fit to HT, LAI, and biomass over thermal time across all replicates within a treatment to obtain a residual mean square error (rmse) and an approximate $r^{2}$ (calculated as 1 - residual sums of squares/corrected total sums of squares) for the treatment.

To evaluate the effects of planting date and weed interference on sweet corn development, the number of leaves counted at the V4 and V8 stages of development in each subplot were subjected to ANOVA using PROC MIXED as described above. To determine differences in time of silk emergence, the percentage of 10 plants within each subplot at the R1 stage of development also was compared using ANOVA. Finally, as an estimate of developmental differences at harvest, the percentage moisture and SSC of harvested ears was compared among treatments using ANOVA.

\section{RESULTS AND DISCUSSION \\ Precipitation, Thermal Units, and Weed Community}

Early planted sweet corn received $40 \%$ more water than LATE in 2004, but treatments received equivalent water in 2005, primarily due to irrigation in that year (Williams, 2006). Monthly average daily air temperature was cooler in 2004 than 2005 during the months of June, July, and August (Table 1). During these months, average temperatures were $1.8^{\circ} \mathrm{C}$ cooler than the 30 -yr average in 2004 , but $1.3^{\circ} \mathrm{C}$ warmer than the long-term average in 2005. Consistent temperatures throughout the growing season in 2004 resulted in relatively small differences in GDD accumulation between planting date treatments in 2004, where LATE sweet corn accumulated slightly greater heat units between 10 and $50 \mathrm{~d}$ after emergence compared with EARLY (Fig. 1). The warm temperatures in late June, July, and August of 2005 resulted in rapid GDD accumulation immediately after LATE planting in 2005, such that large differences in GDD accumulation occurred between planting date treatments in that year.

Weed species common to the U.S. Corn Belt began emerging within $2 \mathrm{~d}$ of sweet corn emergence. Dominant species included barnyardgrass, common lambsquarters, common purslane, green foxtail, redroot pigweed, and velvetleaf. Total weed densities in weedy plots were high, ranging from 226 to 300 plants $\mathrm{m}^{-2}$ at $\mathrm{R} 1$ in 2004 and 95 to 256 plants $\mathrm{m}^{-2}$ at $\mathrm{R} 1$ in 2005 (data not shown). Despite high weed seedling densities, weed canopy density varied by planting date as evidenced by $>70 \%$ shorter weed canopy and $>80 \%$ lower weed biomass LATE compared with EARLY at the time of crop harvest (data not shown). Additional details of weed community characteristics are described in Williams (2006).

\section{Height}

Equation [1] explained at least $96 \%$ of the variance in sweet corn height in relation to thermal time from emergence (Table 2). Sweet corn hybrid 'GH0937' used in this study was 15 to $25 \%$ shorter than dent corn at similar stages in Nebraska (Barker et al., 2006). However, sweet corn height varies from 150 to $300 \mathrm{~cm}$ among commercial hybrids used in the north-central USA (Bisikwa, 2001; Williams et al., 2006). Averaged over weed interference levels, sweet corn grew 13 to $24 \mathrm{~cm}$ taller $\left(\mathrm{HT}_{\max }\right)$ in the LATE compared to EARLY (Fig. 2) treatments in both years and weed interference reduced absolute height growth rate $\left(\mathrm{HT}_{\max } b / 6\right)$ by 6 to $12 \%$ (Table 2). Hunter et al. (1974) observed increases in corn stem length as temperatures increased from 20

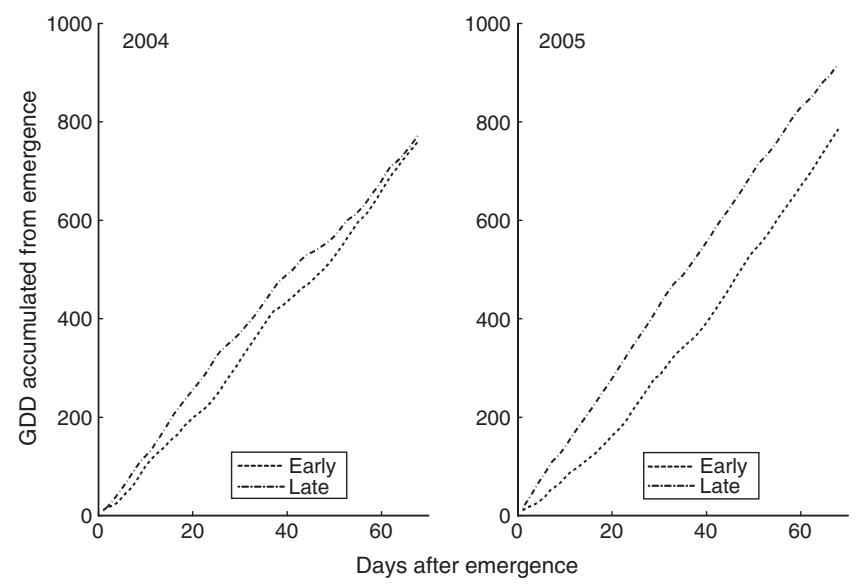

Fig. 1. Growing degree days (GDD) accumulated from emergence in relation to days after emergence for two planting dates in 2004 and 2005 at Urbana, IL. EARLY refers to a planting date the first week of May and LATE refers to a planting date the third week of June. 
Table 2. Sweet corn maximum height (HT ${ }_{\text {max }}$ ), thermal time of maximum absolute growth rate ( $a / b$ from Eq. [1] fitted to HT on GDD), and weighted mean absolute growth rate over the entire growing season $\left(\mathrm{HT}_{\max } b / 6\right.$, when $\left.c=1\right)$ as influenced by planting date $(\mathrm{PD})$ and weed interference (INT) in 2004 and 2005. Residual mean square error (rmse) and approximate $r^{2}\left(\sim r^{2}\right)$ are from the fit of Eq. [1] on HT over GDD across all replicates of each treatment. $P$ values from analysis of variance of parameter estimates fitted to each experimental unit shown below means.

\begin{tabular}{|c|c|c|c|c|c|c|c|c|}
\hline PD & INT & $H_{\text {max }}$ & $a$ & $\boldsymbol{b}$ & $a l b$ & $\mathrm{HT}_{\max } b / 6$ & rmse & $\sim r^{2}$ \\
\hline & & cm & & & GDD & $\mathrm{cm} \mathrm{gdd}^{-1}$ & & \\
\hline & & & & 2004 & & & & \\
\hline \multirow[t]{2}{*}{ Early } & weed-free & 213 & 4.42 & 0.0115 & 385 & 0.408 & 106.2 & 0.99 \\
\hline & weedy & 195 & 4.38 & 0.0114 & 385 & 0.372 & 159.6 & 0.98 \\
\hline \multirow[t]{6}{*}{ Late } & weed-free & 220 & 3.91 & 0.0105 & 372 & 0.385 & 52.04 & 0.99 \\
\hline & weedy & 213 & 3.91 & 0.0107 & 368 & 0.377 & 99.69 & 0.99 \\
\hline & PD & $<0.001$ & $<0.001$ & $<0.001$ & $<\mathbf{0 . 0 0 1}$ & 0.05 & & \\
\hline & INT & $<\mathbf{0 . 0 0 1}$ & 0.58 & 0.95 & 0.25 & $<\mathbf{0 . 0 0 1}$ & & \\
\hline & $\mathbf{P D} \times \mathbf{I N T}$ & 0.006 & 0.48 & 0.20 & 0.20 & 0.003 & & \\
\hline & & & & 2005 & & & & \\
\hline \multirow[t]{2}{*}{ Early } & weed-free & 184 & 3.90 & 0.0095 & 409 & 0.292 & 71.72 & 0.99 \\
\hline & weedy & 213 & 3.57 & 0.0077 & 510 & 0.254 & 195.7 & 0.96 \\
\hline \multirow[t]{5}{*}{ Late } & weed-free & 221 & 4.66 & 0.0105 & 444 & 0.385 & 88.83 & 0.99 \\
\hline & weedy & 224 & 4.36 & 0.0095 & 462 & 0.352 & 79.35 & 0.99 \\
\hline & PD & $<\mathbf{0 . 0 0 1}$ & $<0.001$ & $<0.001$ & 0.71 & $<0.001$ & & \\
\hline & INT & 0.02 & $<0.001$ & $<0.001$ & $<0.001$ & $<0.001$ & & \\
\hline & $\mathbf{P D} \times \mathbf{I N T}$ & 0.16 & 0.81 & 0.16 & 0.01 & 0.72 & & \\
\hline
\end{tabular}

to $30^{\circ} \mathrm{C}$. Therefore, observed differences in height between planting dates appear correlated with temperature, since late-planted sweet corn accumulated thermal time more quickly than the EARLY treatment, especially in 2005 (Fig. 1).

Planting date and weed interference had an interaction effect on sweet corn height growth. Weed interference influenced maximum corn height the most in the EARLY treatment. However, the direction of sweet corn response was inconsistent between years. EARLY weed-free sweet corn $(213 \mathrm{~cm})$ was taller than weedy plots $(195 \mathrm{~cm})$ in 2004 , whereas the inverse was observed in $2005(184 \mathrm{~cm}$ in weed-free and $213 \mathrm{~cm}$ in weedy) (Table 2). As evidenced by magnitude of crop yield loss, the effect of weed interference was more severe EARLY compared to LATE (Williams, 2006). Differential effect of weed interference on crop height EARLY suggests conditions in 2004 may have resulted in resource limitations different than in 2005.

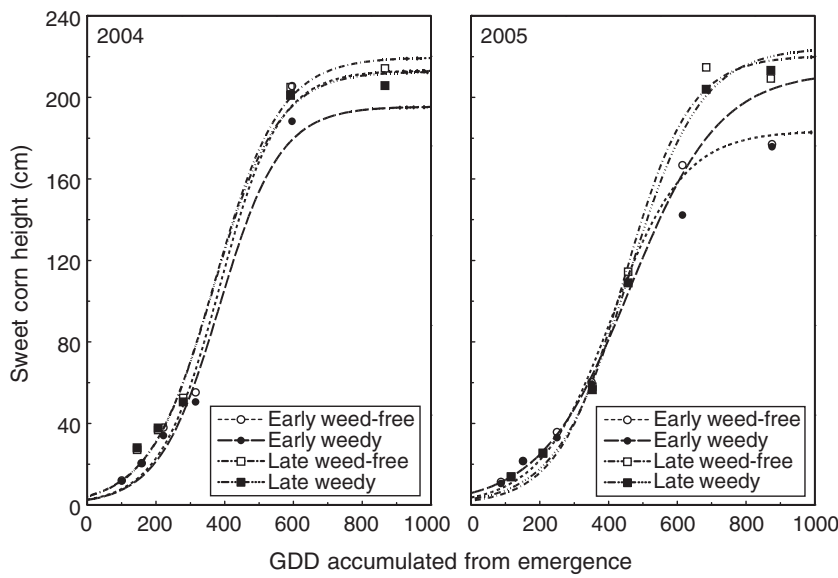

Fig. 2. Sweet corn height in relation to growing degree days (GDD) accumulated from emergence as influenced by planting date and weed interference in 2004 and 2005 . Symbols represent the mean of four replicates and lines represent best fit of Eq. [1] on height. EARLY refers to a planting date the first week of May and LATE refers to a planting date the third week of June.

\section{Leaf Area Index}

Growth in LAI was strongly affected by planting date and by weed interference (Fig. 3). Equation [1] explained at least 89 and $62 \%$ of the variance in sweet corn LAI in relation to thermal time from emergence in 2004 and 2005, respectively (Table 3 ). Weed interference reduced maximum sweet corn LAI and LAI growth rate. For instance, maximum LAI ( $\mathrm{LAI}_{\max }$ ) was reduced 23 to $33 \%$ by weed interference EARLY, while absolute LAI growth rate $\left(\mathrm{LAI}_{\max } b / 6\right)$ was reduced 11 to $40 \%$ by weed interference EARLY (Table 3). Though similar reductions due to weed interference were observed LATE in 2005, there was no effect of weed interference on LAI in the LATE treatment in 2004. Hall et al. (1992) and Evans et al. (2003) observed similar leaf area reductions due to weed interference. Eleven to $40 \%$ lower absolute LAI growth rate in weedy plots, relative to weed-free (Table 3), indicates reductions in maximum sweet corn leaf area were likely the result of weed interference inhibiting leaf emergence or leaf area expansion, as opposed to accelerating leaf senescence.

Late-planted sweet corn had 27 to $44 \%$ less maximum LAI relative to the EARLY treatment. Similar reductions in dent corn LAI and leaf dry matter were observed throughout the growing season near Lincoln, $\mathrm{NE}$, when comparing early May to mid-June planting dates (Swanson and Wilhelm, 1996). Though leaf area was not reported, Hunter et al. (1974) reported no effect of temperature $\left(20-30^{\circ} \mathrm{C}\right)$ on total leaf number. However, reducing the photoperiod from 20 to $10 \mathrm{~h}$ decreased the number of leaves $22 \%$ on average. Photoperiod of the LATE planted sweet corn was steadily declining compared with the EARLY treatment, where photoperiod increased to a maximum near 21 June followed by declining daylength. Differences in photoperiod among treatments may have contributed to the reduced LAI of the LATE treatment. Growth of dent and sweet corn are influenced by interactions between planting date and cultivar (Darby and Lauer, 2002; Kwabiah, 2004; Lauer et al., 1999). 


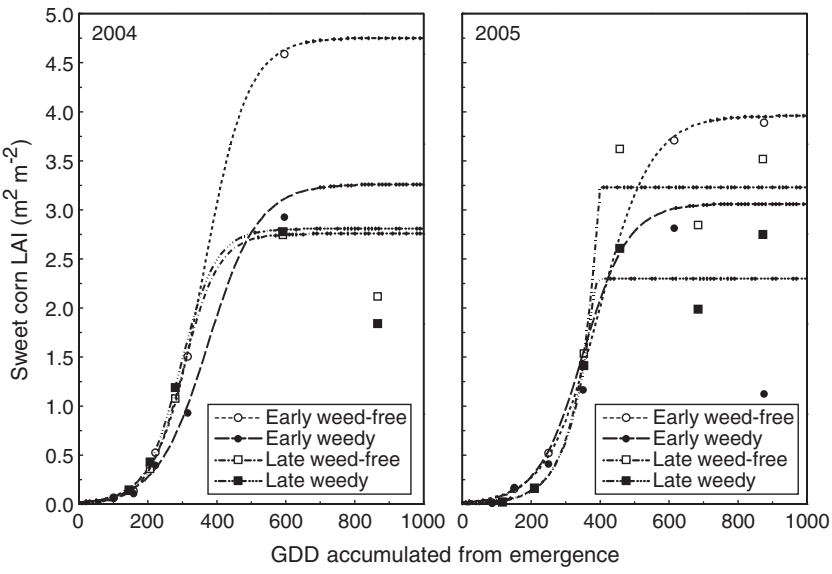

Fig. 3. Sweet corn leaf area index (LAI) in relation to growing degree days (GDD) accumulated from emergence as influenced by planting date and weed interference in 2004 and 2005. Symbols represent the mean of four replicates and lines represent best fit of Eq. [1] on LAI. EARLY refers to a planting date the first week of May and LATE refers to a planting date the third week of June.

\section{Biomass}

Growth in biomass was affected by planting date, weed interference, and their interaction in both years (Fig. 4). Equation [1] explained at least 95 and $54 \%$ of the variance in sweet corn biomass in relation to thermal time from emergence in 2004 and 2005, respectively (Table 4). Compared to EARLY planting, the LATE planting date resulted in greater maximum crop biomass and lower biomass growth rate, resulting in more thermal time (GDD) required to achieve maximal biomass. For instance, weed-free maximum crop biomass $\left(\mathrm{BIO}_{\max }\right)$ was 1255 and $1902 \mathrm{~g} \mathrm{~m}^{-2}$ LATE in 2004 and 2005, respectively, compared with 973 and $1795 \mathrm{~g} \mathrm{~m}^{-2}$ in EARLY weed-free treatments (Table 4). Similar differences in absolute biomass growth rates $\left(\mathrm{BIO}_{\max } b / 6\right)$ among weed-free plots resulted in LATE plots requiring an additional 121 and 170 GDD to achieve maximal biomass $(a / b)$ in 2004 and 2005, respectively (Table 4). Contrary to our observations, Darby and Lauer (2002) observed a decline in total crop biomass from an early May to a late-June planting date in Wisconsin.

While parameter estimates obtained from the fit of Eq. [1] on biomass over thermal time do not clearly show the trend, Fig. 4 shows that weed interference always reduced sweet corn biomass by R1 and later. Results at the R1 sampling date show that the reduction in sweet corn biomass owing to weed interference was greatest in the EARLY (31\%) compared with the LATE (3\%) treatment in 2004 (Fig. 4). Similarly, sweet corn maximum biomass at harvest was reduced $74 \%$ by weed interference in the EARLY 2005 treatment but was unaffected in the LATE treatment in that year (Table 4).

\section{Development}

Early season weed interference had no effect on leaf emergence, as evidenced by insignificant $p$ values for leaf number at the V4 growth stage of sweet corn (Table 5). By the V8 growth stage, weed interference began to influence leaf number in sweet corn. Weedy treatments EARLY in 2004 had an average of 1.1 fewer leaves than weed-free sweet corn, though planting date did not affect leaf number in $2005(p=0.20)$ (Table 5). The cumulative effect of weed interference delayed silk emergence in EARLY weedy plots. As an example, only 2 to $35 \%$ of plants had emerged silks in EARLY weedy plots at a time when $83 \%$ or more of plants had emerged silks in weed-free plots (Table 5). Delays in dent corn silk emergence due to weed interference have been reported previously, and are influenced by hybrid (Tollenaar et al., 1997) and N level (Tollenaar et al., 1994).

Delay in crop development from weed interference, as evidenced by delayed silk emergence, might result in variable maturity among weed interference treatments. However, only weak effects of weed interference were observed in kernel moisture $(p=0.07)$ and SSC $(p=$ 0.04 ) in 1 of $2 \mathrm{yr}$ (Table 5). Inherent in the design of these experiments was that only fully developed ears (diameter of $>4.4 \mathrm{~cm}$ ) were harvested and analyzed. Fewer ears were harvested from weedy plots, particu-

Table 3. Sweet corn maximum LAI (LAI $I_{\text {max }}$ ), thermal time of maximum absolute growth rate ( $a / b$ from Eq. [1] fitted to LAI on GDD, when $c=1)$, and weighted mean absolute growth rate over the entire growing season $\left\{\mathbf{L A} \mathbf{I}_{\max } b /[2(c+2)]\right\}$ as influenced by planting date (PD) and weed interference (INT) in 2004 and 2005. Residual mean square error (rmse) and approximate $r^{2}\left(\sim r^{2}\right)$ are from the fit of Eq. [1] on LAI over GDD across all replicates of each treatment. $P$ values from analysis of variance of parameter estimates fitted to each experimental unit shown below means.

\begin{tabular}{|c|c|c|c|c|c|c|c|c|c|}
\hline PD & INT & $\mathbf{L A} \mathbf{I}_{\max }$ & $a$ & $b$ & $c$ & $a / b$ & $\mathbf{L A I}_{\max } \times b /[2(c+2)]$ & rmse & $\sim \boldsymbol{r}^{2}$ \\
\hline & & $\mathrm{m}^{2} \mathrm{~m}^{-2}$ & & & 2004 & GDD & $\mathrm{m}^{2} \mathrm{~m}^{-2} \mathrm{gdd}^{-1}$ & & \\
\hline \multirow[t]{2}{*}{ Early } & weed-free & 4.75 & 5.62 & 0.0155 & 1.0 & 364 & 0.0121 & 0.1446 & 0.96 \\
\hline & weedy & 3.26 & 5.10 & 0.0136 & 1.0 & 384 & 0.0072 & 0.1593 & 0.89 \\
\hline \multirow[t]{5}{*}{ Late } & weed-free & 2.76 & 5.87 & 0.0194 & 1.0 & 303 & 0.0090 & 0.0224 & 0.98 \\
\hline & weedy & 2.81 & 5.74 & 0.0195 & 1.0 & 301 & 0.0090 & 0.0475 & 0.96 \\
\hline & PD & $<\mathbf{0 . 0 0 1}$ & $<\mathbf{0 . 0 0 1}$ & $<\mathbf{0 . 0 0 1}$ & & $<0.001$ & 0.06 & & \\
\hline & INT & $<\mathbf{0 . 0 0 1}$ & 0.004 & 0.15 & & 0.26 & $<\mathbf{0 . 0 0 1}$ & & \\
\hline & $\mathbf{P D} \times \mathbf{I N T}$ & $<\mathbf{0 . 0 0 1}$ & 0.071 & 0.11 & & 0.18 & $<\mathbf{0 . 0 0 1}$ & & \\
\hline \multicolumn{10}{|c|}{2005} \\
\hline \multirow[t]{2}{*}{ Early } & weed-free & 3.96 & 5.26 & 0.0132 & 1.0 & 402 & 0.0089 & 0.2005 & 0.92 \\
\hline & weedy & 3.06 & 5.35 & 0.0153 & 1.0 & 359 & 0.0079 & 0.7765 & 0.62 \\
\hline \multirow[t]{5}{*}{ Late } & weed-free & 3.23 & 751.0 & 1.8816 & 117.1 & N/A & 0.0255 & 0.2138 & 0.92 \\
\hline & weedy & 2.30 & 93.5 & 0.2431 & 15.95 & $\mathbf{N} / \mathbf{A}$ & 0.0156 & 0.1586 & 0.88 \\
\hline & PD & 0.003 & $<\mathbf{0 . 0 0 1}$ & $<0.001$ & & N/A & $<0.001$ & & \\
\hline & INT & $<\mathbf{0 . 0 0 1}$ & $<\mathbf{0 . 0 0 1}$ & $<\mathbf{0 . 0 0 1}$ & & $<\mathbf{0 . 0 0 1}$ & $<\mathbf{0 . 0 0 1}$ & & \\
\hline & $\mathbf{P D} \times \mathbf{I N T}$ & 0.96 & $<\mathbf{0 . 0 0 1}$ & $<0.001$ & & N/A & $<\mathbf{0 . 0 0 1}$ & & \\
\hline
\end{tabular}




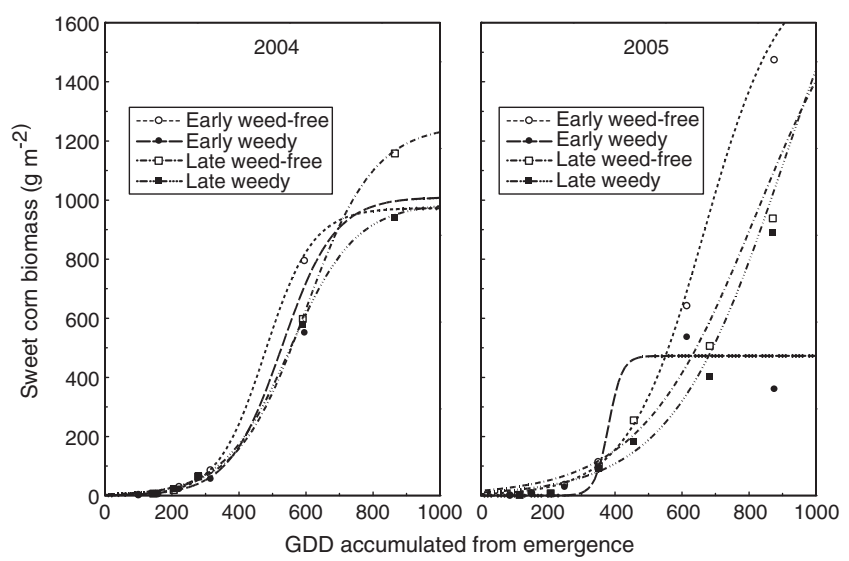

Fig. 4. Sweet corn total aboveground biomass in relation to growing degree days (GDD) accumulated from emergence as influenced by planting date and weed interference in 2004 and 2005. Symbols represent the mean of four replicates and lines represent best fit of Eq. [1] on biomass. EARLY refers to a planting date the first week of May and LATE refers to a planting date the third week of June.

larly in the EARLY treatment (Williams, 2006), indicating weed interference delayed (or ceased) the crop's ability to produce fully developed ears in weedy plots. Therefore, our data on kernel moisture and SSC reflect the effect of weed interference on marketable ears, but underestimate the effect that weed interference had on plants that produced underdeveloped ears.

Though initial weed density ( $>95$ weeds $\mathrm{m}^{-2}$ ) was high in both years and planting dates, the degree of competition for individual limited resources in each environment is difficult to ascertain. Crop yield data (Williams, 2006) indicated that EARLY planted sweet corn endured an overall greater level of weed interference, as evidenced by $85 \%$ maximum yield loss, compared with $15 \%$ maximum yield loss LATE. Sweet corn planted LATE may have greater stress tolerance. High weed biomass EARLY reflects resource availability to the weed community, but low weed biomass LATE could be the result of a more suppressive crop, lower weed growth rate, or a combination of the two factors.
Table 5. Sweet corn development as influenced by planting date (PD) and weed interference (INT) in 2004 and 2005. Columns headed with V4 and V8 show the mean number of leaves plant $^{-1}$ in each treatment at a sampling time corresponding to the targeted V4 and V8 leaf stages. The R1 (silk emergence) column reports the mean percentage of 10 consecutive plants $\operatorname{plot}^{-1}$ with emerged silks. Moisture and soluble solids concentration (SSC) columns report the mean percent water and SSC of sweet corn kernels at harvest.

\begin{tabular}{|c|c|c|c|c|c|c|}
\hline PD & INT & V4 & v8 & R1 & Moisture & SSC \\
\hline & & \multicolumn{2}{|c|}{$\begin{array}{r}- \text { no. leaves }- \\
\underline{2004}\end{array}$} & & $-\%$ & \\
\hline \multirow[t]{2}{*}{ Early } & weed-free & 3.88 & 8.10 & 82.5 & 72.5 & 24.48 \\
\hline & weedy & 3.85 & 7.00 & 2.5 & 74.7 & $\begin{array}{l}22.75 \\
23.65\end{array}$ \\
\hline \multirow[t]{6}{*}{ Late } & weed-free & 3.88 & 7.85 & 87.5 & 66.9 & 23.65 \\
\hline & weedy & 3.93 & 7.90 & 95.0 & 68.1 & $\begin{array}{r}21.63 \\
0.24\end{array}$ \\
\hline & PD & 0.61 & 0.14 & $<0.001$ & $<0.001$ & 0.24 \\
\hline & INT & 0.86 & 0.03 & $<0.001$ & 0.07 & 0.04 \\
\hline & $\mathbf{P D} \times \mathbf{I N T}$ & 0.61 & 0.02 & $<0.001$ & 0.60 & 0.85 \\
\hline & & & 2005 & & & \\
\hline \multirow[t]{2}{*}{ Early } & weed-free & 4.03 & 7.25 & 87.5 & 70.7 & 24.7 \\
\hline & weedy & 3.95 & 6.93 & 35.0 & 70.4 & 25.6 \\
\hline \multirow[t]{5}{*}{ Late } & weed-free & 3.68 & 7.28 & 100 & 59.9 & 23.2 \\
\hline & weedy & 3.90 & 7.03 & 100 & 59.6 & 24.3 \\
\hline & PD & 0.08 & 0.77 & 0.01 & $<0.001$ & 0.07 \\
\hline & INT & 0.49 & 0.20 & 0.06 & 0.81 & 0.16 \\
\hline & $\mathbf{P D} \times \mathbf{I N T}$ & 0.18 & 0.86 & 0.06 & 0.98 & 0.84 \\
\hline
\end{tabular}

Nonetheless, weed interference consistently reduced sweet corn's absolute height growth rate, maximum LAI, absolute LAI growth rate, with some of the largest effects on crop growth observed in the EARLY planting date. In addition, silk emergence was delayed by weeds for EARLY planted sweet corn, but not LATE. The LATE planting date consistently resulted in taller crop plants with greater shoot biomass, yet with lower maximum LAI, indicating a greater proportion of shoot biomass was partitioned to stems and reproductive tissues relative to the EARLY treatment.

Typical dates for sweet corn planting in the northcentral USA influence crop canopy development. This variation in canopy development influences the crop's ability to endure competitive stress and suppress weeds, resulting in interactive effects of planting date and weed

Table 4. Sweet corn maximum total aboveground biomass $\left(\mathrm{BIO}_{\max }\right)$, thermal time of maximum absolute growth rate (a/b from Eq. [1] fitted to BIO on GDD), and weighted mean absolute growth rate over the entire growing season $\left(\mathrm{BIO}_{\max } b / 6\right.$, when $\left.c=1\right)$ as influenced by planting date (PD) and weed interference (INT) in 2004 and 2005. Residual mean square error (rmse) and approximate $r^{2}\left(\sim r^{2}\right)$ are from the fit of Eq. [1] on BIO over GDD across all replicates of each treatment. $P$ values from analysis of variance of parameter estimates fitted to each experimental unit shown below means.

\begin{tabular}{|c|c|c|c|c|c|c|c|c|}
\hline PD & INT & BIO $_{\max }$ & $a$ & $\boldsymbol{b}$ & $a / b$ & $\mathrm{BIO}_{\max } b / 6$ & rmse & $\sim \boldsymbol{r}^{2}$ \\
\hline & & $\mathrm{g} \mathrm{m}^{-2}$ & & 2004 & GDD & $\mathrm{g} \mathrm{m}^{-2} \mathrm{gdd}^{-1}$ & & \\
\hline \multirow[t]{2}{*}{ Early } & weed-free & 973 & 6.74 & 0.0141 & 480 & 2.26 & 3772 & 0.97 \\
\hline & weedy & 1010 & 6.71 & 0.0127 & 543 & 2.01 & 2618 & 0.95 \\
\hline \multirow[t]{6}{*}{ Late } & weed-free & 1255 & 5.81 & 0.0097 & 601 & 2.03 & 3965 & 0.98 \\
\hline & weedy & 989 & 5.61 & 0.0102 & 555 & 1.65 & 3861 & 0.98 \\
\hline & PD & 0.04 & $<\mathbf{0 . 0 0 1}$ & $<\mathbf{0 . 0 0 1}$ & $<\mathbf{0 . 0 0 1}$ & 0.003 & & \\
\hline & INT & 0.07 & 0.02 & 0.07 & 0.46 & 0.002 & & \\
\hline & $\mathbf{P D} \times \mathbf{I N T}$ & 0.02 & 0.08 & $<\mathbf{0 . 0 0 1}$ & $<\mathbf{0 . 0 0 1}$ & 0.52 & & \\
\hline & & & & $\underline{2005}$ & & & & \\
\hline \multirow[t]{2}{*}{ Early } & weed-free & 1795 & 5.88 & 0.0088 & 672 & 2.55 & 35108 & 0.90 \\
\hline & weedy & 473 & 18.60 & 0.0489 & 449 & 5.80 & 37669 & 0.54 \\
\hline \multirow[t]{5}{*}{ Late } & weed-free & 1902 & 4.75 & 0.0058 & 842 & 1.74 & 5698 & 0.96 \\
\hline & weedy & 2242 & 5.36 & 0.0059 & 918 & 2.12 & 2181 & 0.98 \\
\hline & PD & $<\mathbf{0 . 0 0 1}$ & $<\mathbf{0 . 0 0 1}$ & $<\mathbf{0 . 0 0 1}$ & $<\mathbf{0 . 0 0 1}$ & 0.005 & & \\
\hline & INT & $<\mathbf{0 . 0 0 1}$ & 0.001 & $<\mathbf{0 . 0 0 1}$ & $<\mathbf{0 . 0 0 1}$ & 0.02 & & \\
\hline & $\mathbf{P D} \times \mathbf{I N T}$ & $<\mathbf{0 . 0 0 1}$ & 0.003 & $<\mathbf{0 . 0 0 1}$ & $<\mathbf{0 . 0 0 1}$ & 0.07 & & \\
\hline
\end{tabular}


interference on the crop. Under central Illinois conditions and weeds common to the region, sweet corn growth likely contributes to the crop having a distinct competitive advantage when planted mid-June, compared with early May planting. These results explain, in part, the influence of planting date on CPWC of weed control in sweet corn reported by Williams (2006).

\section{ACKNOWLEDGMENTS}

We appreciate the technical expertise of John Frihauf and Ryan Hasty and assistance from students Brian Philiben, Nathan Smith, and Yim So.

\section{REFERENCES}

Anapalli, S.S., L. Ma, D.C. Nielsen, M.F. Vigil, and L.R. Ahuja. 2005. Simulating planting date effects on corn production using RZWQM and CERES-maize models. Agron. J. 97:58-71.

Barker, D.C., S.Z. Knezevic, A.R. Martin, D.T. Walters, and J.L. Lindquist. 2006. Effect of nitrogen addition on the comparative productivity of corn and velvetleaf (Abutilon theophrasti). Weed Sci. 54:354-363.

Begna, S.H., R.I. Hamilton, L.M. Dwyer, D.W. Stewart, D. Cloutier, L. Assemat, K. Foroutan-pour, and D.L. Smith. 2001. Morphology and yield response to weed pressure by corn hybrids differing in canopy architecture. Eur. J. Agron. 14:293-302.

Bisikwa, J. 2001. Effects of canopy density on growth and development of wild proso millet and giant foxtail. MS thesis. Univ. of Minnesota, St. Paul.

Buhler, D.D., and J.L. Gunsolus. 1996. Effect of date of preplant tillage and planting on weed populations and mechanical weed control in soybean (Glycine max). Weed Sci. 44:373-379.

Darby, H.M., and J.G. Lauer. 2002. Planting date and hybrid influence on corn forage yield and quality. Agron. J. 94:281-289.

Evans, S.P., S.Z. Knezevic, J.L. Lindquist, C.A. Shapiro, and E.E. Blankenship. 2003. Nitrogen application influences the critical period for weed control in corn. Weed Sci. 51:408-417.

Gower, S.A., M.M. Loux, J. Cardina, and S.K. Harrison. 2002. Effect of planting date, residual herbicide, and postemergent application timing on weed control and grain yield in glyphosate-tolerant corn. Weed Technol. 16:488-494.

Hale, T.A., R.L. Hassell, and T. Phillips. 2005. Refractometer measurements of soluble solid concentrations do not reliably predict sugar content in sweet corn. HortTechnology 15:668-672.

Hall, M.R., C.J. Swanton, and G.W. Anderson. 1992. The critical period of weed control in grain corn (Zea mays). Weed Sci. 40:441-447.

Hunt, R. 1982. Plant growth curves: The functional approach to growth analysis. Edward Arnold Publ., Ltd., London.

Hunter, R.B., L.A. Hunt, and L.W. Kannenberg. 1974. Photoperiod and temperature effects on corn. Can. J. Plant Sci. 54:71-78.

Illinois State Water Survey. 2005. Climate data for ChampaignUrbana. Available at www.sws.uiuc.edu/atmos/statecli/Champ-Urb/ CU.htm (accessed 10 Oct. 2005; verified 11 Apr. 2007). Illinois State Water Survey, Champaign, IL.

Jannink, J.L., J.H. Orf, N.R. Jordan, and R.G. Shaw. 2000. Index selection for weed suppressive ability in soybean. Crop Sci. 40: 1087-1094

Jordan, N. 1993. Prospects for weed control through crop interference. Ecol. Appl. 3:84-91.
Kwabiah, A.B. 2004. Growth and yield of sweet corn (Zea mays L.) cultivars in response to planting date and plastic mulch in a shortseason environment. Sci. Hortic. (Amsterdam) 102:147-166.

Lauer, J.G., P.R. Carter, T.M. Wood, G. Diezel, D.W. Wiersma, R.E. Rand, and M.J. Mlynarek. 1999. Corn hybrid response to planting date in the northern corn belt. Agron. J. 91:834-839.

Lemerle, D., A. Smith, B. Verbeek, E. Koetz, P. Lockley, and P. Martin. 2006. Incremental crop tolerance to weeds: A measure for selecting competitive ability in Australian wheats. Euphytica 149:85-95.

Lindquist, J.L., and D.A. Mortensen. 1998. Tolerance and velvetleaf (Abutilon theophrasti) suppressive ability of two old and two modern corn (Zea mays) hybrids. Weed Sci. 46:569-574.

Littell, R.C., G.A. Milliken, W.W. Stroup, and R.D. Wolfinger. 1996. SAS system for mixed models. SAS Inst., Cary, NC.

Mulder, T.A., and J.D. Doll. 1994. Reduced input corn weed control: The effects of planting date, early season weed control, and rowcrop cultivator selection. J. Prod. Agric. 7:256-260.

Nielsen, R.L., P.R. Thomison, G.A. Brown, A.L. Halter, J. Wells, and K.L. Wuethrich. 2002. Delayed planting effects on flowering and grain maturation of dent corn. Agron. J. 94:549-558.

Norsworthy, J.K., and M.J. Oliveira. 2004. Comparison of the critical period for weed control in wide- and narrow-row corn. Weed Sci. 52:802-807.

Nurse, R.E., and A. DiTommaso. 2005. Corn competition alters the germinability of velvetleaf (Abutilon theophrasti) seeds. Weed Sci. 53:479-488.

Pataky, J.K. 1994. Effects of races 0 and 1 of Exserohilum turcicum on sweet corn hybrids differing for $H t$ - and partial resistance to northern leaf blight. Plant Dis. 78:1189-1193.

Ritchie, S.W., J.J. Hanway, G.O. Benson, and J.C. Herman. 2003. How a corn plant develops. Special Rep. 48 (revised). Iowa State Univ. of Sciences and Technology, Coop. Ext. Serv., Ames.

SAS Institute. 1990. SAS/STAT users guide. Version 6. 4th ed. SAS Inst., Cary, NC.

Swanson, S.P., and W.W. Wilhelm. 1996. Planting date and residue rate effects on growth, partitioning, and yield of corn. Agron. J. 88:205-210.

Tharp, B.E., and J.J. Kells. 2001. Effect of glufosinate-resistant corn (Zea mays) population and row spacing on light interception, corn yield, common lambsquarters (Chenopodium album) growth. Weed Technol. 15:413-418.

Toler, J.E., E.C. Murdock, G.S. Stapleton, and S.U. Wallace. 1999. Corn leaf orientation effects on light interception, intraspecific competition, and grain yields. J. Prod. Agric. 12:396-399.

Tollenaar, M., A. Aguilera, and S.P. Nissanka. 1997. Grain yield is reduced more by weed interference in an old than in a new maize hybrid. Agron. J. 89:239-246.

Tollenaar, M., S.P. Nissanka, A. Aguilera, S.F. Weise, and C.J. Swanton. 1994. Effect of weed interference and soil nitrogen on four maize hybrids. Agron. J. 86:596-601.

Tollenaar, M., and J. Wu. 1999. Yield improvement in temperate maize is attributable to greater stress tolerance. Crop Sci. 39:1597-1604.

Tracy, W.F. 2001. Sweet corn. p. 155-197. In A.R. Hallauer (ed.) Specialty corns. 2nd ed. CRC Press, Boca Raton, FL.

Williams, M.M., II. 2006. Planting date influences critical period of weed control in sweet corn. Weed Sci. 54:928-933.

Williams, M.M., II, R. Boydston, and A.S. Davis. 2006. Canopy variation among three sweet corn hybrids and implications for light competition. HortScience 41:1-6.

Williams, M.M., II, R. Boydston, and A.S. Davis. 2007. Wild proso millet (Panicum miliaceum) suppressive ability among three sweet corn hybrids. Weed Sci. 55:245-251. 